\title{
Vitamin D and PTH: data from a cross-sectional study in an equatorial population
}

\author{
Natércia Neves Marques de Queiroz, Franciane Trindade Cunha de Melo, Fabrício de Souza Resende, \\ Luísa Corrêa Janaú, Norberto Jorge Kzan de Souza Neto, Manuela Nascimento de Lemos, \\ Ana Carolina Lobato Virgolino, Maria Clara Neres lunes de Oliveira, Angélica Leite de Alcântara, \\ Lorena Vilhena de Moraes, Tiago Franco David, Wanderson Maia da Silva, Scarlatt Souza Reis, \\ Márcia Costa dos Santos, Ana Carolina Contente Braga de Souza, Pedro Paulo Freire Piani, \\ Neyla Arroyo Lara Mourão, Karem Mileo Felício, João Felício Abrahão Neto and João Soares Felício \\ University Hospital João de Barros Barreto, Federal University of Pará, Endocrinology Division, Belem, Pará, Brazil
}

Correspondence should be addressed to J S Felício: felicio.bel@terra.com.br

\begin{abstract}
Objective: Investigate the prevalence of vitamin D deficiency in an equatorial population through a large-sample study.

Methods: Cross-sectional study with 30,224 healthy individuals from the North Region, in Brazil (Amazônia - state of Pará), who had 25-hydroxy-vitamin D (25(OH)D) and intact parathyroid hormone (PTH) serum levels measured by immunoassay method. Those with history of acute or chronic diseases were excluded. Abnormal levels of calcium, creatinine, glycemia and albumin were also exclusion criteria.

Results: 25(OH)D levels were $29.1 \pm 8.2 \mathrm{ng} / \mathrm{mL}$ and values $<12.7 \mathrm{ng} / \mathrm{mL}$ were equal to $<-2$ s.D. below average. Hypovitaminosis D was present in $10 \%$ of subjects according to the Institute of Medicine (values $<20 \mathrm{ng} / \mathrm{mL}$ ) and in $59 \%$, in consonance with Endocrine Society (values $20-30 \mathrm{ng} / \mathrm{mL}$ as insufficiency and $<20 \mathrm{ng} / \mathrm{mL}$ as deficiency) criteria. Individuals were divided according to four age brackets: children, adolescents, adults and elderly, and their 25(OH)D levels were: $33 \pm 9 ; 28.5 \pm 7.4 ; 28.3 \pm 7.7 ; 29.3 \pm 8.5 \mathrm{ng} / \mathrm{mL}$, respectively. All groups differed in $25(\mathrm{OH}) \mathrm{D}$, except adolescents vs adults. Regression model showed BMI, sex, living zone (urban or rural) and age as independent variables to $25(\mathrm{OH}) \mathrm{D}$ levels. Comparing subjects with vitamin D deficiency $(<20 \mathrm{ng} / \mathrm{mL}$ ) to those with vitamin $D$ insufficiency $(20-30 \mathrm{ng} / \mathrm{mL})$, a difference between PTH levels in these two groups was observed $(95.9 \pm 24.7 \mathrm{pg} / \mathrm{mL}$ vs $44.2 \pm 64.5 \mathrm{pg} / \mathrm{mL} ; P<0.01)$. Additionally, the most accurate predictive vitamin $D$ level for subclinical hyperparathyroidism in ROC curve was $26 \mathrm{ng} / \mathrm{mL}$.

Conclusion: Our equatorial population showed low prevalence of vitamin D hypovitaminosis ranging with age bracket. The insufficient category by Endocrine Society was corroborated by our PTH data.
\end{abstract}

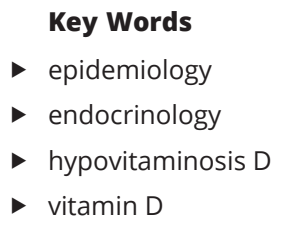

Endocrine Connections (2020) 9, 667-675

\section{Introduction}

The Institute of Medicine (IOM) defines normality of vitamin $\mathrm{D}$ as serum 25-hydroxy-vitamin D (25(OH)D) levels above $20 \mathrm{ng} / \mathrm{mL}$, based on the dietary intake needed to meet the requirements for at least $97.5 \%$ of the population (1). According to this criterion, several studies worldwide have shown high rates of hypovitaminosis D, with an estimate of 30-40\%, in European, Asian, African and South American countries (2, 3, 4). Therefore, hypovitaminosis $\mathrm{D}$ has been listed as a public health problem, as one billion people presented $25(\mathrm{OH}) \mathrm{D}$

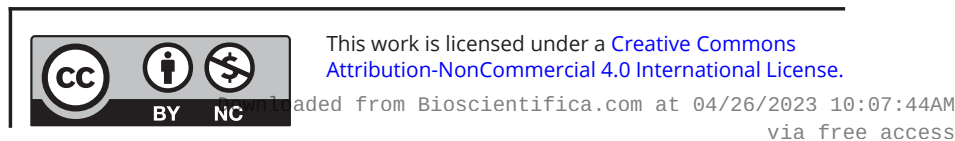


deficiency (4), with a prevalence ranging from 2 to $90 \%$, depending on cut-off points and selected population (5).

In addition, Manson et al. (6), in 2016, in a re-analysis of IOM data, suggested there was an overestimation in the diagnosis of hypovitaminosis $\mathrm{D}$ and believed that sufficiency is reached when serum vitamin D is above $12.5 \mathrm{ng} / \mathrm{mL}$. Bouillon (7), in a review, stated that all guidelines are unanimous in recommending avoidance of 25(OH)D levels below $10 \mathrm{ng} / \mathrm{mL}$, as well as highlighted the controversy involving levels between 10 and $20 \mathrm{ng} / \mathrm{mL}$, which might not indicate deficiency necessarily for the whole population.

Besides the global controversy, large population studies trying to evaluate vitamin D levels in equatorial populations are rare. Little data are available from a small number of locations such as Kenya, DR Congo and Colombia $(2,8)$. In Brazil, few studies have been carried out to demonstrate the hypovitaminosis $\mathrm{D}$ prevalence in healthy subjects. Therewithal, given the country's length, there is considerable climatic difference between the regions and, as far as we are aware, there is no previous study in the Amazonian region. Therefore, it remains unclear whether the current diagnostic criterion for vitamin $\mathrm{D}$ deficiency might cause overdiagnosis of this condition. In this context, investigating the prevalence of vitamin D deficiency in an equatorial population, such as ours, through a large-sample study becomes meaningfully important.

\section{Method}

\section{Study design and data collection}

A cross-sectional study was performed to evaluate serum levels of 25(OH)D, intact PTH and ionized calcium. All our subjects lived in the state of Pará (coordinates: $3.95^{\circ} \mathrm{S}$ $53.09^{\circ} \mathrm{W}$ ), located in the North Region of Brazil (Fig. 1). Being near the Equator, Pará constantly experiences hot climate and humid weather with little seasonal variation, as do most equatorial areas, which is the reason we did not include seasonality in this study (9). Usual UV index throughout the year ranges from 8 to 10 , being classified as 'very high', based on World Health Organization (WHO) criteria $(10,11)$. Total mean insolation is $2241.6 \mathrm{~h} /$ year and total mean irradiation is $5.05 \mathrm{kWh} / \mathrm{m}^{2}$ day $(12,13)$. Data were collected from January to December 2019.

A total of 30,224 subjects of both sexes and different age groups who had 25(OH)D serum levels measured at a local laboratory service from January to December of

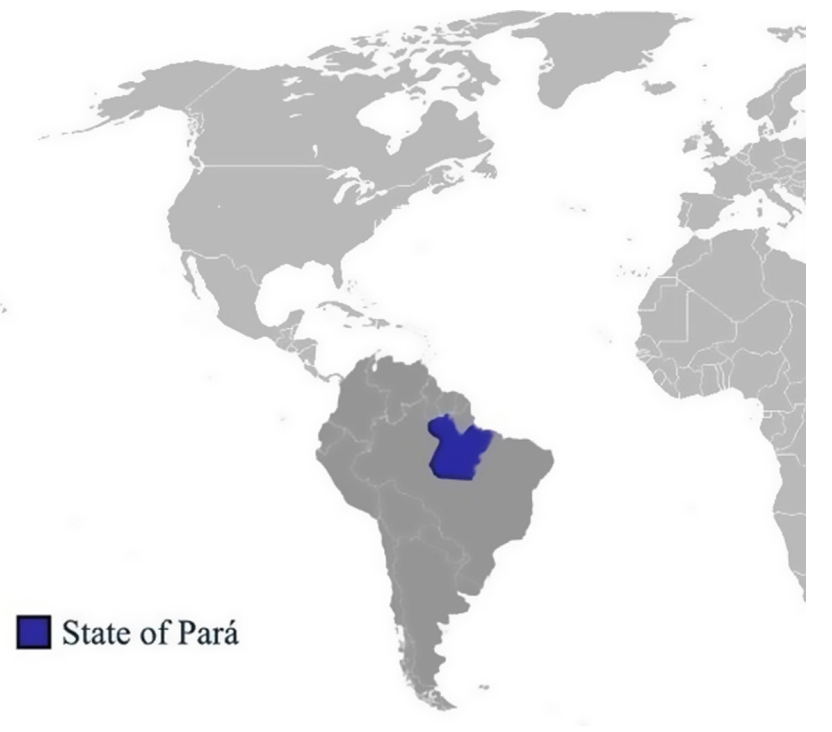

Figure 1

State of Pará (North Region, Brazil).

2019 were included in the study. All subjects answered a questionnaire; those with previous history of acute or chronic diseases (hypertension, chronic kidney failure, chronic liver disease, autoimmune diseases) were excluded, as well as pregnant women and those taking any medications, including patients who supplemented vitamin D. Subjects who presented abnormal results of serum ionized calcium, creatinine, glycemia and serum albumin were also not eligible (reference values: 1.1-1.3 $\mathrm{mmol} / \mathrm{L}, \quad 0.7-1.3 \mathrm{mg} / \mathrm{dL}$ (men) and $0.6-1.1 \mathrm{mg} / \mathrm{dL}$ (women), 3.2-4.8 $\mathrm{g} / \mathrm{dL}$, respectively). Individuals who had both vitamin D and PTH collected were divided into a smaller group of 1629 healthy individuals and were analyzed separately, in order to properly interpret their data.

Information regarding age, sex, BMI and living zone were collected. Patients were divided according to the age groups defined by WHO, in 2013, as children (0-9 years old), teenagers (10-19 years old), adults (20-59 years old) and elderly (above 60 years old). The impact of seasonality was not evaluated because there are not established patterns of seasons in our region $(14,15)$. This study was approved by University Hospital João de Barros Barreto Ethics Committee, CAAE number 66977717.8.0000.0017.

\section{Assay}

Individuals' blood was collected and, then, serum 25(OH)D was measured quantitatively by the following kit: DiaSorin LIAISON 25-OH-Vitamin D TOTAL

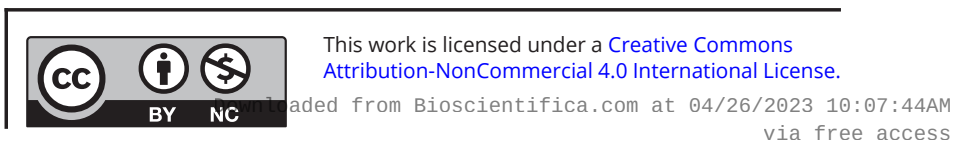


chemiluminescence immunoassay (DiaSorin, Stillwater, MN, USA) (16). DiaSorin LIAISON is one of the methods to evaluate 25(OH)D tested by DEQAS (Vitamin D External Quality Assessment Scheme), the largest specialist external quality assessment (proficiency testing) scheme for the vitamin D metabolites $25(\mathrm{OH}) \mathrm{D}$ and 1,25(OH)2D, thus reinforcing the accuracy of our analysis (17). Quantitative serum intact parathyroid hormone (PTH) was determined by electrochemiluminescence (Modular Analytics, E170, Roche). Serum albumin was assessed by enzymatic methodology. Concentration of plasmatic glucose was determined by the hexokinase method. Creatinine was measured through kinetic alkaline picrate assays. Ionized calcium was calculated based on total calcium, protein and albumin.

\section{Statistical analysis}

Vitamin D was tested for its normal distribution through the Kolmogorov-Smirnov test. The mean and the s.D. of $25(\mathrm{OH}) \mathrm{D}$ levels were calculated. To establish correlations between 25(OH)D levels and variables such as sex, age, BMI and living zone (urban or rural), Pearson or Spearman tests were used. Stepwise multiple regression analysis and simple linear regression were also performed to evaluate the degree of influence of other variables in serum 25(OH)D levels. The SPSS Statistics $22^{\circledR}$ (IBM Corp.) and RStudio IDE (RStudio, Inc.) software were used for quantitative statistical analysis. The $P$ value $<0.05$ was considered statistically significant.

As for the subjects dosed for intact PTH, a receiver operating characteristic (ROC) curve was constructed to determine the most accurate vitamin $\mathrm{D}$ level to predict subclinical hyperparathyroidism (SHT). The cut-off point with maximum sensitivity and specificity in the ROC curve was defined as the minimum value in the equation $\left((1-\text { sensitivity })^{2}+(1-\right.$ specificity $\left.)\right)$ and the precision was estimated based on the area under the ROC curve.

\section{Results}

In our study, 30,224 individuals of both sexes and different age groups were analyzed. The age of the subjects was $40.4 \pm 21.4$ years, ranging from 0 to $104(42 \pm 20.4$ in females vs $36 \pm 23.5$ in males, $P<0.001)$ and BMI was $25.6 \pm 5.2 \mathrm{~kg} / \mathrm{m}^{2}$. Regarding sex, 22,325 (74\%) were female and 7899 (26\%) were male. They were divided into four age groups: children (0-9 years old), adolescents (10-19), adults (20-59) and elderly ( $\geq 60)$. In our study, there were 3801 (12.6\%) children, 2150 (7.1\%) adolescents, $18,320(60.6 \%)$ adults and 5953 (19.7\%) elderly. 25(OH) D levels were $29.1 \pm 8.2 \mathrm{ng} / \mathrm{mL}$ and values $<12.7 \mathrm{ng} / \mathrm{mL}$ were equal to $<-2$ s.D. below average. All groups differed in age and BMI, as shown in Table 1. Regarding the distribution of vitamin $\mathrm{D}$ levels according to each age bracket in our population, all groups differed between one another, except adolescents vs adults (Fig. 2 and Table 1). Furthermore, regarding sex, 25(OH)D levels were higher in males in all groups (Table 2). Only 324 subjects (1\%) were below -2 s.D. The median (25th-75th percentile) was $28.3 \mathrm{ng} / \mathrm{mL}$ (23.7-33.5). Hypovitaminosis D was present in $10 \%$ (3140) of subjects according to the Institute of Medicine (in which abnormal values are those $<20 \mathrm{ng} / \mathrm{mL})$ and in $59 \%(17,847)$, in consonance with Endocrine Society (which defines values between 20 and $30 \mathrm{ng} / \mathrm{mL}$ as insufficiency and values $<20 \mathrm{ng} / \mathrm{mL}$ as deficiency) criteria. The prevalence of hypovitaminosis $\mathrm{D}$ around the world and in our population (according to age groups) is summarized in Tables 3 and 4.

The subjects were from 107 different cities in the state of Pará and those living in urban areas showed lower $25(\mathrm{OH}) \mathrm{D}$ levels when compared to those living in rural areas $(30.3$ vs $28.7 \mathrm{ng} / \mathrm{mL}, P<0.001)$.

The levels of 25(OH)D correlated with BMI $(r=-0.2$; $P<0.001)$ and age $(r=-0.1 ; P<0.01)$. Our forward stepwise regression model showed BMI, sex, living zone and age as independent variables to $25(\mathrm{OH}) \mathrm{D}$ levels $(\mathrm{B}=-0.271$ (CI: -0.290 to -0.252 ), $r^{2}=0.023, P<0.001 ; \mathrm{B}=2.911$ (CI: 2.697-3.126), $r^{2}=0.023, P<0.001 ; \mathrm{B}=-1.763$ (CI: -2.057 to -1.468$), r^{2}=0.005, P<0.001 ; B=0.019$ (CI: 0.014-0.024),

Table 1 Clinical and laboratory characteristics according to age groups.

\begin{tabular}{|c|c|c|c|}
\hline & Children & Adolescents & Adults \\
\hline & $n=3801$ & $n=2150$ & $n=18,320$ \\
\hline Age (years) & $6.4 \pm 3.3$ & $16 \pm 2.3$ & $40.3 \pm 10.7$ \\
\hline $\operatorname{Sex}(F / M)(\%)$ & $52 / 48$ & $66 / 34$ & $79 / 21$ \\
\hline $25(\mathrm{OH}) \mathrm{D}(\mathrm{ng} / \mathrm{mL})$ & $33 \pm 9$ & $28.5 \pm 7.4$ & $28.3 \pm 7.7$ \\
\hline $\mathrm{BMI}\left(\mathrm{kg} / \mathrm{m}^{2}\right)$ & $19 \pm 4.6$ & $22.8 \pm 4.7$ & $26.5 \pm 4.6$ \\
\hline
\end{tabular}

\begin{tabular}{ccc}
\hline Elderly & \multicolumn{1}{c}{} \\
\hline$n=5953$ & $<0.001^{\mathrm{a}}$ \\
\hline $71.1 \pm 8.5$ & $<0.001^{\mathrm{a}}$ \\
$75 / 25$ & $<0.001^{\mathrm{b}}$ \\
$29.3 \pm 8.5$ & $<0.001^{\mathrm{a}}$ \\
$26.8 \pm 4.6$ &
\end{tabular}

all groups. ${ }^{\circ} P<0.05$ between all age groups except adults vs adolescents $(P=0.182)$

https://ec.bioscientifica.com

https://doi.org/10.1530/EC-20-0206 (c) 2020 The authors Published by Bioscientifica Ltd

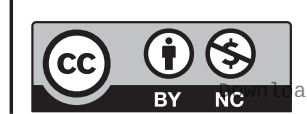

This work is licensed under a Creative Commons Attribution-NonCommercial 4.0 International License. ded from Bioscientifica.com at 04/26/2023 10:07:44AM via free access 


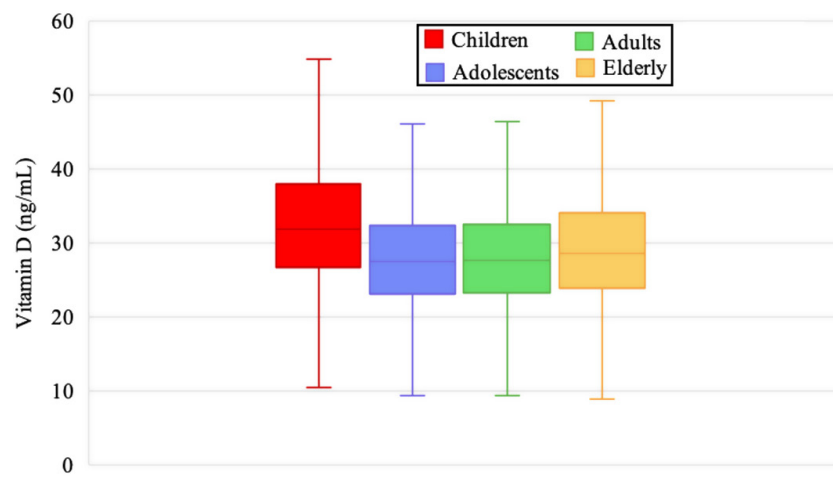

Figure 2

25(OH)D distribution according to age bracket.

$\left.r^{2}=0.002, P<0.001\right)$. These variables showed a poor prediction power, altogether being capable of determining only $5.4 \%$ of $25(\mathrm{OH}) \mathrm{D}$ levels. An inclination coefficient of -0.235 was obtained using BMI and vitamin D level as variables in a simple linear regression model according to the formula vitamin $\mathrm{D}$ level $=35.002-(0.235 \times \mathrm{BMI})$, which suggests that, for each BMI unit gained, there would be a decrease of $0.235 \mathrm{ng} / \mathrm{mL}$ in vitamin $\mathrm{D}$ levels.

The 1692 subjects who had PTH analyzed were divided into two subgroups according to $25(\mathrm{OH}) \mathrm{D}$ levels: subgroup $1 \quad(<20 \mathrm{ng} / \mathrm{mL})$ and subgroup 2 (20-30 ng/mL). A difference between PTH levels in these two groups was observed $(95.9 \pm 24.7 \mathrm{pg} / \mathrm{mL}$ vs $44.2 \pm 64.5 \mathrm{pg} / \mathrm{mL} ; P<0.01)$. The proportion of individuals with abnormal PTH, in subjects with vitamin D deficiency or insufficiency according to Endocrine Society, is presented in Fig. 3. In addition, the percentage of functional hypoparathyroidism (hypovitaminosis D with normal PTH levels) among patients with vitamin D insufficiency (20-30 ng/mL) and deficiency $(<20 \mathrm{ng} / \mathrm{mL})$ was $91.7 \%$ and $77.2 \%$, respectively $(P<0.01)$.

According to the ROC curve, the vitamin $D$ value established as the cut-off point for PTH response to vitamin $\mathrm{D}$ insufficiency and, in consequence, for increased risk of bone loss, in our sample was $26 \mathrm{ng} / \mathrm{mL}$, with sensitivity of $54.8 \%$, specificity of $63.2 \%$ and accuracy of $58.5 \%$. The ROC curve also presented accuracy of $58.5 \%$, positive likelihood ratio of 1.49 and negative likelihood ratio of 0.72 . In addition, we found that in 152 (9\%) of our 1692 individuals who had PTH analyzed showed subclinical hyperparathyroidism.

\section{Discussion}

Our study showed low prevalence of hypovitaminosis D, ranging with age bracket, when compared to other countries, according to both IOM and Endocrine Society (ES) criteria, even when compared to other equatorial populations. In addition, the insufficient category by ES was corroborated by our PTH data.

Currently, due to laboratory assays and the variability of their cut-off points, 25(OH)D levels above $30 \mathrm{ng} / \mathrm{mL}$ are accepted as appropriate by Endocrine Society, once this value would ensure a satisfactory action with no toxicity risk. In 2011, ES defined values between 20 and $30 \mathrm{ng} / \mathrm{mL}$ as insufficiency and values $<20 \mathrm{ng} / \mathrm{mL}$ as deficiency (18). IOM, based on the dietary intake needed to meet the requirements of the population, established vitamin $\mathrm{D}$ deficiency as levels $<20 \mathrm{ng} / \mathrm{mL}(19,20)$. They also suggest that each population should establish their specific criteria to decide about 25(OH)D supplementation. Nevertheless, Manson et al. (6), while assessing data from the National Health and Nutrition Examination Survey (NHANES), suggested $<12.5 \mathrm{ng} / \mathrm{mL}$ as a cut-off. If Manson's proposition were used in our population, prevalence of vitamin $\mathrm{D}$ hypovitaminosis would be extremely low compared to other countries in the equatorial zone $(2,8)$. Therefore, it could indicate that specific population factors, such as latitude and mean insolation, might be of great importance to determine serum levels of 25(OH)D.

In Brazil, few population studies address this aspect. Unger (21) performed a transversal study in São Paulo, evaluating 603 volunteers aged 18-90 years in 2007. The author found that $77.4 \%$ of the participants showed vitamin D insufficiency and 19.3\% showed 25(OH)D deficiency. Scalco et al., in a research with 102 noninstitutionalized seniors, found that the prevalence of vitamin D hypovitaminosis was higher (87.5\%) (22). Finally, Linhares et al. studying 226 children at Recife,

Table 2 25(OH)D levels (ng/mL) according to sex, separated into age groups.

\begin{tabular}{|c|c|c|}
\hline Age/sex & $n$ & I \\
\hline General & 30,224 & 31. \\
\hline Children & 3801 & 3 \\
\hline Adolescents & 2150 & 30 \\
\hline Adults & 18,320 & 29. \\
\hline Elderly & 5953 & 32. \\
\hline
\end{tabular}

Male
$31.2 \pm 8.8$
$34 \pm 9.3$
$30.1 \pm 7.9$
$29.8 \pm 8.3$
$32.2 \pm 9.1$

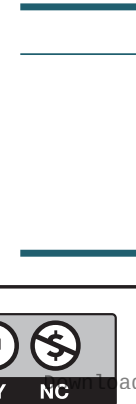

Female

$28.3 \pm 7.8$

$32 \pm 8.7$

$27 \pm 6.9$

$27.9 \pm 7.5$

$28.4 \pm 8.1$

\begin{tabular}{c}
\hline $\boldsymbol{P}$ \\
\hline$<0.001$ \\
$<0.001$ \\
$<0.001$ \\
$<0.001$ \\
$<0.001$
\end{tabular}

This work is licensed under a Creative Commons Attribution-NonCommercial 4.0 International License. ded from Bioscientifica.com at 04/26/2023 10:07:44AM 
Table 3 Prevalence of 25(OH)D deficiency in different countries.

\begin{tabular}{|c|c|}
\hline Reference & Country \\
\hline Queiroz et al. (2020) & North Brazil \\
\hline Mogire et al. (2019) & Africa countries \\
\hline Cashman et al. (2016) & Europe \\
\hline Eloi et al. (2016) & $\begin{array}{l}\text { Southeast Brazil } \\
\text { (São Paulo) }\end{array}$ \\
\hline Kiani et al. (2015) & Pakistan \\
\hline Ramnemark et al. (2015) & Northern Sweden \\
\hline Gill et al. (2014) & $\begin{array}{l}\text { Northeast } \\
\text { Australia }\end{array}$ \\
\hline Unger et al. (2010) & $\begin{array}{l}\text { Southeast Brazil } \\
\text { (São Paulo) }\end{array}$ \\
\hline
\end{tabular}

\begin{tabular}{c}
\hline $\boldsymbol{n}$ \\
\hline 30,224 \\
21,474 \\
55,844 \\
39,004 \\
500 \\
1622 \\
2413 \\
603 \\
\hline
\end{tabular}

\begin{tabular}{c}
\hline Age range \\
\hline $0-104$ \\
$0-90$ \\
$1-99$ \\
$2-95$ \\
$1.6-92$ \\
$25-74$ \\
$24-95$ \\
$18-90$
\end{tabular}

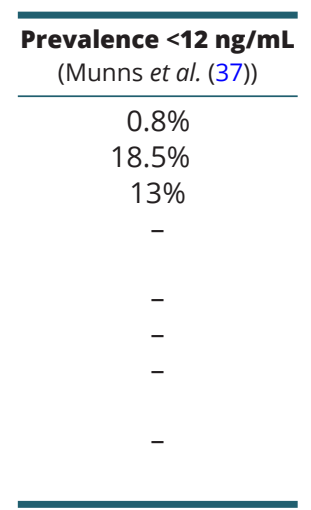

\begin{tabular}{c}
\hline $\begin{array}{c}\text { Prevalence } \\
<\mathbf{2 0} \mathbf{~ n g} / \mathbf{m L} \text { (IOM) }\end{array}$ \\
\hline $10.3 \%$ \\
$34.2 \%$ \\
$40.4 \%$ \\
$33.9 \%$ \\
- \\
$20.8 \%$ \\
$22.7 \%$ \\
-
\end{tabular}

\begin{tabular}{c}
\hline $\begin{array}{c}\text { Prevalence } \\
<30 \text { ng/mL (ES) }\end{array}$ \\
\hline $59 \%$ \\
$59.5 \%$ \\
- \\
$70.7 \%$ \\
$87.6 \%$ \\
- \\
- \\
$78 \%$ \\
\hline
\end{tabular}

ES, Endocrine Society; IOM, Institute of Medicine.

Brazil, did not find cases of vitamin D deficiency (23). All those studies used Endocrine Society parameters of normality. The first two studies occurred in the South-Southeast region of Brazil $\left(22^{\circ}-33^{\circ} \mathrm{S}\right)$, with lower mean insolation, which could justify the higher hypovitaminosis D prevalence compared to our data. The third study, which evaluated just a selected children population, found no case of hypovitaminosis D and occurred in the Northeast region of Brazil, in a city with latitude close to ours. Those last findings suggest that latitude, mean insolation and age must be considered when establishing normal vitamin $\mathrm{D}$ values in a population, which reinforces our findings about age bracket influence on vitamin D.

In addition, we found higher levels of 25(OH)D in males. One possible explanation would be a greater sun exposure of the thorax - which is a region of better absorption of $25(\mathrm{OH}) \mathrm{D}$. Our results are in agreement with the findings of Al-Ghamdi (24) and Kiani et al. (25). The former evaluated 150 subjects from Saudi Arabia and observed vitamin D lower in girls, probably because of their dressing costumes. In Amazonia, due to

Table 4 Prevalence of vitamin D deficiency in our population according to different criteria.

\begin{tabular}{|c|c|c|c|}
\hline $\begin{array}{l}\text { Vitamin D } \\
\text { cut-offs (ng/mL) }\end{array}$ & $<12$ (Munns et al. (56)) & $<\mathbf{2 0}(\mathrm{IOM})$ & $<30$ (ES) \\
\hline $\begin{array}{l}\text { Children (\%) } \\
n=3801\end{array}$ & 0.1 & 4.5 & 40.9 \\
\hline $\begin{array}{l}\text { Adolescents (\%) } \\
n=2150\end{array}$ & 0.8 & 12.2 & 64.2 \\
\hline $\begin{array}{l}\text { Adults (\%) } \\
n=18,320\end{array}$ & 0.9 & 11.3 & 62.9 \\
\hline $\begin{array}{l}\text { Elderly }(\%) \\
n=5953\end{array}$ & 1.1 & 10.5 & 57.0 \\
\hline $\begin{array}{l}\text { Total }(\%) \\
n=30,224\end{array}$ & 0.8 & 10.4 & 59.0 \\
\hline $\begin{array}{l}\text { https://ec.bioscientific } \\
\text { https://doi.org/10.15 }\end{array}$ & $\begin{array}{l}. \text { com } \\
\text { /EC-20-0206 }\end{array}$ & Published & $\begin{array}{l}20 \text { The aut } \\
\text { ioscientific }\end{array}$ \\
\hline
\end{tabular}

the hot weather, men usually dress shirtless and, consequently, have a higher thorax exposure. Another hypothesis would be the influence of testosterone levels. It has been suggested that testosterone levels could be associated with higher 25(OH)D levels $(26,27,28,29)$. In fact, Araujo et al. also described vitamin D levels higher in males than in females, also suggesting this hormonal influence (30). A possible mechanism that could explain this association is not well established.

Our data also showed a decrease in circulating concentrations of serum $25(\mathrm{OH}) \mathrm{D}$ while BMI increased, which indicates that poor vitamin D levels are linked with higher BMI. The proposed mechanisms to explain this include a lack of sun exposure, modified vitamin D

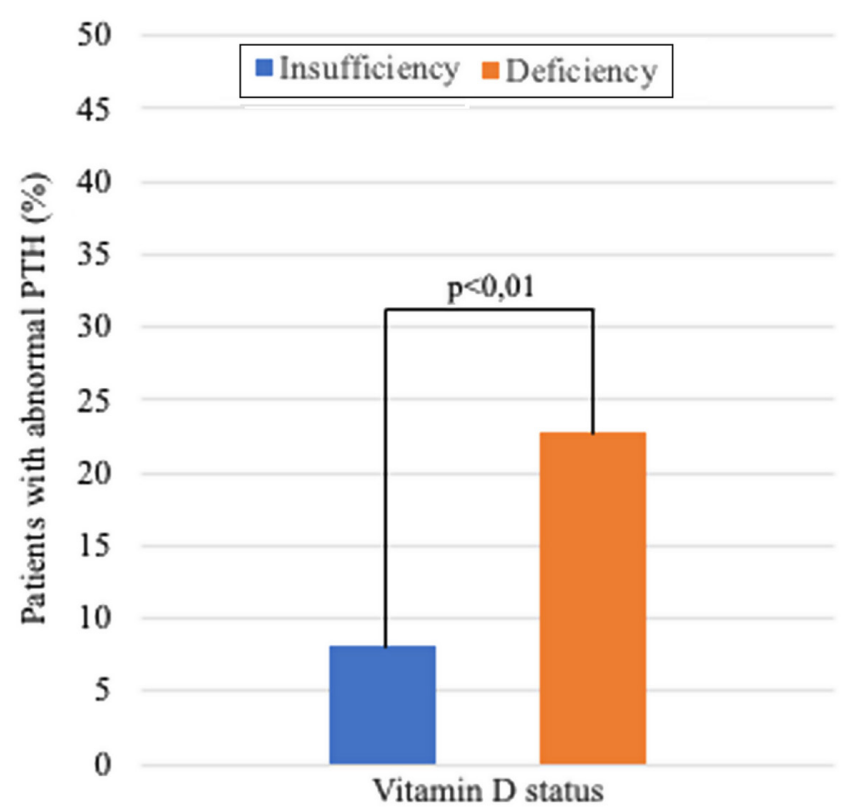

Figure 3

Distribution of patients with secondary hyperparathyroidism according to vitamin D status (Endocrine Society).

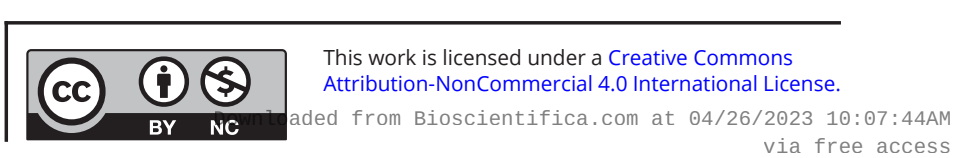


activation and increased vitamin $\mathrm{D}$ storage in adipose tissue $(18,31,32)$. Indeed, obese individuals expose themselves less to solar UV radiation, diminishing cutaneous synthesis of vitamin D3 from 7-dehydrocholesterol (32). It was showed, in a study with obese patients, a higher prevalence of hypovitaminosis in this group, as none of them had the habit of sunbathing. Their clothes used to cover as much skin as possible, generating the hypothesis that low concentrations of vitamin D may be related to low sun exposure in those patients (32).

Eloi et al. (33), in a similar research in São Paulo, based on the ES, performed an investigation in patients aged from 2 to 95 years, and observed vitamin D concentrations $<20 \mathrm{ng} / \mathrm{mL}$ in $33.9 \%$ of the patients, presenting higher vitamin D levels in summer (38.4\%) when compared to winter (23.3\%). In our study, it was not possible to assess this issue, due to the lack of proper season distinction in the state of Pará, which is situated near the Equator line presenting higher insolation throughout the year.

Our study showed that people living in rural areas have higher vitamin D levels. This finding agrees with a meta-analysis that took place in African countries recently (2). However, it remains a controversial topic. Fang et al. (34), in a study based in China, with 1814 subjects, showed slightly higher vitamin D levels among urban residents compared to rural ones, but also pointed out that its results are opposed to many similar researches in Asia $(35,36,37,38)$. Similarly, an Indian study demonstrated lower 25(OH)D levels in rural subjects despite plentiful sun exposure (39). In our region, the dressing habits of countryside inhabitants, such as using lighter and fewer clothes, and the fact that rural areas have less impairment of sun exposure due to shorter buildings could influence our results. In fact, KimLi et al. (40) established skin exposure as the single strongest contributor to the explained variance in $25(\mathrm{OH}) \mathrm{D}$. However, this issue needs to be better analyzed.

The variables studied in our regression model showed a low predictive power, being capable of determining only $5.4 \%$ of $25(\mathrm{OH}) \mathrm{D}$ levels. An important hypothesis that could explain these findings is the assessment of polymorphism consequences for the vitamin $\mathrm{D}$ receptor (VDR) function. This individual genetic diversity could play a central role in determining $25(\mathrm{OH}) \mathrm{D}$ levels $(41,42$, $43,44)$. According to Nissen (45), who analyzed twentyfive different genetic variants in seven different genes, it was concluded that polymorphisms in the CYP2R1 and $G C$ genes are associated with serum variations in the vitamin D. In this same perspective, Husain et al. (46), who compared Americans with European and African ancestry with similar lifestyles and demographic conditions, demonstrated that those with African ancestry had lower $25(\mathrm{OH}) \mathrm{D}$ values. Both studies suggest that specific ethnic and genetic determinants may influence vitamin D levels. In Brazil, the expressive miscegenation makes ethnic analysis difficult. This could explain the difference between hypovitaminosis $\mathrm{D}$ prevalence in our study when compared to those from the rest of the world.

Analyzing the ROC curve in this study, we found that vitamin D level of $26 \mathrm{ng} / \mathrm{mL}$ is the best cut-off point for the PTH response to vitamin D insufficiency and, consequently, for increased risk of bone loss. It suggests that subjects with vitamin D levels lower than $26 \mathrm{ng} / \mathrm{mL}$ could have an additional benefit in supplementation, since a large number of people who fit in this condition are asymptomatic to SHP. According to ES definitions, this value is classified as insufficiency, reinforcing that this group of individuals should receive special attention in clinical practice.

Another aspect that should be addressed is the method for assessing vitamin D. Liquid chromatographymass spectrometry is considered the gold standard for measuring $25(\mathrm{OH}) \mathrm{D}$. It has the advantage of allowing sample adaptation and high specificity; however, it is a complex, expensive and rarely available assay (47). The automated immunoassay is the most widely used method globally, standardized in clinical practice, as it is easier to perform, faster and less costly $(47,48)$. In our study, aiming at the clinical applicability of the findings, the automated immunoassay was used.

In Brazil, low vitamin D intake is commonly observed. Filgueiras et al. (49) found an elevated prevalence of inadequate vitamin D intake (91.3\%) among 378 children. Peters et al. (50), studying 136 adolescents, and Cembranel et al. (51), assessing 1051 patients between 22 and 63 years, described that $85.1 \%$ and $100 \%$ of subjects did not meet the daily adequate intake recommendation of vitamin D. In 2013, a National Dietary Survey with Brazilian elderly stated that our region had more adequate levels of vitamin D intake when compared to other regions of Brazil, even though inadequacy was still very present (52). This might contribute to the lower prevalence of vitamin D hypovitaminosis in our population.

Skin pigmentation also might have an influence in vitamin D levels. Libon et al. (53), in a research with Fitzpatrick skin types II, III (fair-skinned) and VI (blackskinned) individuals, found that after a single total body UVB exposure fair-skinned people presented higher levels of vitamin D when compared to black-skinned people. In agreement, a systematic review conducted by

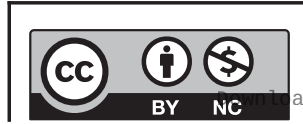

This work is licensed under a Creative Commons Attribution-NonCommercial 4.0 International License. ded from Bioscientifica.com at 04/26/2023 10:07:44AM 
Xiang et al. (54) concludes that vitamin D production was less effective in those with pigmented skin. In the North region of Brazil, black people correspond solely to $6.5 \%$ of the population (55). This also might have influenced our results.

In fact, as a limitation of our study, we did not consider the amount of time of exposure to sunlight, skin type and vitamin D daily dietary intake, which are known as important factors impacting serum vitamin D levels.

Finally, the low prevalence of hypovitaminosis D in our population was established by IOM criteria of $20 \mathrm{ng} / \mathrm{mL}$, using data from our 30,224 subjects who performed $25(\mathrm{OH}) \mathrm{D}$ serum dosage. On the other hand, the value of $26 \mathrm{ng} / \mathrm{mL}$ resulted from a ROC curve constructed to determine the most accurate vitamin D level to predict subclinical hyperparathyroidism, which should be considered for treatment in risk groups for bone mass loss, for example. However, it would not be a general population cut-off point.

\section{Conclusion}

Our equatorial population showed low prevalence of vitamin D hypovitaminosis, according to both IOM $(<20$ $\mathrm{ng} / \mathrm{mL})$ and ES criteria $(<30 \mathrm{ng} / \mathrm{mL})$, ranging with age bracket. The insufficient category by Endocrine Society was corroborated by our PTH data. Since our regression model could only determine $5.4 \%$ of the vitamin D levels, the individual characteristics of each subject should be taken into account to establish inadequate levels of vitamin D.

\section{Declaration of interest}

The authors declare that there is no conflict of interest that could be perceived as prejudicing the impartiality of the research reported.

\section{Funding}

This work did not receive any specific grant from any funding agency in the public, commercial, or not-for-profit sector.

\section{Ethics approval and consent to participate}

Our study was approved by the Human Research Ethics Committee. The Committee waived the requirement for written informed consent for participants in this study in accordance with the national legislation, resolution 466/12 (National Health Council) and the institutional requirements due to the fact that it is a database population study with confidentiality and non-identification guarantee.

\section{Consent for publication}

All authors approved the manuscript and consent to this submission.
Availability of data and material

The datasets analyzed during the current study are available from the corresponding author on reasonable request.

\section{Author contribution statement}

All persons who meet authorship criteria are listed as authors, and all authors certify that they have participated sufficiently in the work to take public responsibility for the content, including participation in the concept, design, analysis, writing, or revision of the manuscript. K M F, J S F and $N N$ M Q took part in conception and design of study. A L A, L V M, T F D, N A L M, W M S and A C C B S were responsible for acquisition of data, while LC J, J S F, S SR, N J K S N, P P F P and J FA N have done the analysis and interpretation of data. M N L, A C L V, F T C M, F S R, L M C F and M C N I O have drafted the manuscript together. All authors have revised the manuscript critically and approved the version to be published.

\section{Acknowledgements}

The authors thank Amaral Costa Laboratory and Programa de Pós Graduação em Oncologia e Ciências Médicas of HUJBB for their contribution to the research.

\section{References}

1 Maeda SS, Borba VZC, Camargo MBR, Silva DMW, Borges JLC, Bandeira F, Lazaretti-Castro M \& Brazilian Society of Endocrinology and Metabology (SBEM). Recommendations of the Brazilian Society of Endocrinology and Metabology (SBEM) for the diagnosis and treatment of hypovitaminosis D. Arquivos Brasileiros de Endocrinologia e Metabologia 201458 411-433. (https://doi.org/10.1590/0004-2730000003388)

2 Mogire RM, Mutua A, Kimita W, Kamau A, Bejon P, Pettifor JM, Adeyemo A, Williams TN \& Atkinson SH. Prevalence of vitamin D deficiency in Africa: a systematic review and meta-analysis. Lancet: Global Health 20208 e134-e142. (https://doi.org/10.1016/S2214109X(19)30457-7)

3 Cashman KD, Dowling KG, Škrabáková Z, Gonzalez-Gross M, Valtueña J, De Henauw S, Moreno L, Damsgaard CT, Michaelsen KF, Mølgaard C, et al. Vitamin D deficiency in Europe: pandemic? American Journal of Clinical Nutrition 2016103 1033-1044. (https:// doi.org/10.3945/ajcn.115.120873)

4 Holick MF. The vitamin D deficiency pandemic: approaches for diagnosis, treatment and prevention. Reviews in Endocrine and Metabolic Disorders 201718 153-165. (https://doi.org/10.1007/ s11154-017-9424-1)

5 Hilger J, Friedel A, Herr R, Rausch T, Roos F, Wahl DA, Pierroz DD, Weber P \& Hoffmann K. A systematic review of vitamin D status in populations worldwide. British Journal of Nutrition $201411123-45$. (https://doi.org/10.1017/S0007114513001840)

6 Manson JE, Brannon PM, Rosen CJ \& Taylor CL. Vitamin D deficiency - is there really a pandemic? New England Journal of Medicine 2016375 1817-1820. (https://doi.org/10.1056/ NEJMp1608005)

7 Bouillon R. Comparative analysis of nutritional guidelines for vitamin D. Nature Reviews: Endocrinology 201713 466-479. (https:// doi.org/10.1038/nrendo.2017.31)

8 Hernando VU, Andry MM, María Virginia PF \& Valentina A. Vitamin D nutritional status in the adult population in Colombia - an analytical cross-sectional study. Heliyon 20206 e03479. (https://doi. org/10.1016/j.heliyon.2020.e03479)

9 National Geographic. Equator. Washington, DC, USA: National Geographic. (available at: https://www.nationalgeographic.org/ encyclopedia/equator/)

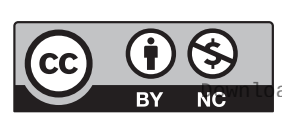

This work is licensed under a Creative Commons Attribution-NonCommercial 4.0 International License. ded from Bioscientifica.com at 04/26/2023 10:07:44AM 
10 NASA earth observations. UV index. Greenbelt, MD, USA: NEO. (available at: https://neo.sci.gsfc.nasa.gov/view. php?datasetId=AURA_UVI_CLIM_M)

11 World Health Organization. Ultraviolet (UV) index. Geneva Switzerland: WHO, 2017. (available at: https://www.who.int/newsroom/q-a-detail/ultraviolet-(uv)-index)

12 National Institute of Meteorology. Meteorological database for teaching and research. Brasília, Brasil: INMET. (available at: http:// www.inmet.gov.br/portal/index.php?r=bdmep/bdmep)

13 National Space Research Institute. Solar and terrestrial radiation. São José dos Campos, Brazil: DSA. (available at: http://satelite.cptec. inpe.br/radiacao/)

14 Machado LAT, Laurent H, Dessay N \& Miranda I. Seasonal and diurnal variability of convection over the Amazonia: a comparison of different vegetation types and large scale forcing. Theoretical and Applied Climatology $2004 \mathbf{7 8}$ 61-77. (https://doi.org/10.1007/s00704004-0044-9)

15 Nobre CA, Obregón GO, Marengo JA, Fu R \& Poveda G. Characteristics of Amazonian climate: main features. In Geophysical Monograph Series, 149-157. Eds M Keller, M Bustamante, J Gash \& PS Dias. Washington, DC, USA: American Geophysical Union, 2009. (https://doi.org/10.1029/2008GM000720).

16 DiaSorin. LIAISON 25 OH vitamin D TOTAL Assay [Brochure]. Stillwater, MN, USA: DiaSorin. (available at: https://www.diasorin. com/en/node/8476)

17 DEQAS. Vitamin D External Quality Assessment Scheme. DEQAS Review 2016/2017. London, UK: DEQAS. (available at: http://www deqas.org/downloads/DEQAS\%20Review\%20October\%202017.pdf)

18 Holick MF, Binkley NC, Bischoff-Ferrari HA, Gordon CM, Hanley DA, Heaney RP, Murad MH, Weaver CM \& Endocrine Society. Evaluation, treatment, and prevention of vitamin D deficiency: an Endocrine Society clinical practice guideline. Journal of Clinical Endocrinology and Metabolism 201196 1911-1930. (https://doi.org/10.1210/jc.20110385)

19 Institute of Medicine (IOM). Dietary reference intakes for calcium and vitamin D. Pediatrics 2012130 e1424. (https://doi.org/10.1542/ peds.2012-2590)

20 Ross AC, Manson JE, Abrams SA, Aloia JF, Brannon PM, Clinton SK, Durazo-Arvizu RA, Gallagher JC, Gallo RL, Jones G, et al. The 2011 report on dietary reference intakes for calcium and vitamin $\mathrm{D}$ from the Institute of Medicine: what clinicians need to know. Journal of Clinical Endocrinology and Metabolism 201196 53-58. (https://doi. org/10.1210/jc.2010-2704).

21 Unger MD. Determinação dos níveis séricos de vitamina D em uma amostra de indivíduos saudáveis da população brasileira. São Paulo. Doctoral Dissertation (Science Doctorate), The Faculty of Medicine of the Univeristy of São Paulo, 2009.

22 Scalco R, Premaor MO, Fröehlich PE \& Furlanetto TW. High prevalence of hypovitaminosis D and secondary hyperparathyroidism in elders living in nonprofit homes in South Brazil. Endocrine 200833 95-100. (https://doi.org/10.1007/s12020008-9061-2)

23 Linhares ER, Jones DA, Round JM \& Edwards RHT. Effect of nutrition on vitamin D status: studies on healthy and poorly nourished Brazilian children. American Journal of Clinical Nutrition 198439 625-630. (https://doi.org/10.1093/ajcn/39.4.625)

24 Al-Ghamdi MA, Lanham-New SA \& Kahn JA. Differences in vitamin D status and calcium metabolism in Saudi Arabian boys and girls aged 6 to 18 years: effects of age, gender, extent of veiling and physical activity with concomitant implications for bone health. Public Health Nutrition 201215 1845-1853. (https://doi.org/10.1017/ S1368980011003612)

25 Kiani RA, Asad MJ, Abbasi S, Farooq N \& Khan MU. Prevalence of vitamin-D deficiency in urban population: a retrospective analysis. Annals of Pakistan Institute of Medical Sciences 201511 90-94.
26 Santos HO, Howell S, Nichols K \& Teixeira FJ. Reviewing the evidence on vitamin D supplementation in the management of testosterone status and its effects on male reproductive system (testis and prostate): mechanistically dazzling but clinically disappointing. Clinical Therapeutics 202042 e101-e114. (https://doi.org/10.1016/j. clinthera.2020.03.016)

27 Pilz S, Frisch S, Koertke H, Kuhn J, Dreier J, Obermayer-Pietsch B, Wehr E \& Zittermann A. Effect of vitamin D supplementation on testosterone levels in men. Hormone and Metabolic Research 201143 223-225. (https://doi.org/10.1055/s-0030-1269854)

28 Wehr E, Pilz S, Boehm BO, März W \& Obermayer-Pietsch B. Association of vitamin D status with serum androgen levels in men. Clinical Endocrinology 200973 243-248. (https://doi.org/10.1111/ j.1365-2265.2009.03777.x)

29 Iyengar R, Maceda C, Beebe H, Crowley L, Woodward M, Barchama N \& McLaughlin MA. MP51-04 association between testosterone, vitamin D and cardiovascular risk. Journal of Urology 2015193 e621. (https://doi.org/10.1016/j.juro.2015.02.1741)

30 Santos Araújo EPD, Queiroz DJM, Neves JPR, Lacerda LM, Gonçalves MDCR \& Carvalho AT. Prevalence of hypovitaminosis $\mathrm{D}$ and associated factors in adolescent students of a capital of Northeastern Brazil. Nutricion Hospitalaria 201734 1416-1423. (https://doi.org/10.20960/nh.1097)

31 Bell NH, Epstein S, Greene A, Shary J, Oexmann MJ \& Shaw S. Evidence for alteration of the vitamin D-endocrine system in obese subjects. Journal of Clinical Investigation 198576 370-373. (https:// doi.org/10.1172/JCI111971)

32 Compston JE, Vedi S, Ledger JE, Webb A, Gazet JC \& Pilkington TR. Vitamin D status and bone histomorphometry in gross obesity. American Journal of Clinical Nutrition 198134 2359-2363. (https:// doi.org/10.1093/ajcn/34.11.2359)

33 Eloi M, Horvath DV, Szejnfeld VL, Ortega JC, Rocha DAC, Szejnfeld J \& Castro CHM. Vitamin D deficiency and seasonal variation over the years in São Paulo, Brazil. Osteoporosis International 201627 3449-3456. (https://doi.org/10.1007/s00198-016-3670-z)

34 Fang F, Wei H, Wang K, Tan L, Zhang W, Ding L, Liu T, Shan Z \& Zhu M. High prevalence of vitamin D deficiency and influencing factors among urban and rural residents in Tianjin, China. Archives of Osteoporosis 201813 64. (https://doi.org/10.1007/s11657-018-0479-8)

35 Choi HS, Oh HJ, Choi H, Choi WH, Kim JG, Kim KM, Kim KJ, Rhee Y \& Lim SK. Vitamin D insufficiency in Korea - a greater threat to younger generation: the Korea National Health and Nutrition Examination Survey (KNHANES) 2008. Journal of Clinical Endocrinology and Metabolism 201196 643-651. (https://doi. org/10.1210/jc.2010-2133)

36 Chen J, Yun C, He Y, Piao J, Yang L \& Yang X. Vitamin D status among the elderly Chinese population: a cross-sectional analysis of the 2010-2013 China national nutrition and health survey (CNNHS). Nutrition Journal 2017 16 3. (https://doi.org/10.1186/s12937-0160224-3.

37 Nurbazlin M, Chee WSS, Rokiah P, Alexander AT, Chew YY, Nusaibah ARS \& Chan SP. Effects of sun exposure on $25(\mathrm{OH})$ vitamin $\mathrm{D}$ concentration in urban and rural women in Malaysia. Asia Pacific Journal of Clinical Nutrition 201322 391-399. (https://doi. org/10.6133/apjcn.2013.22.3.15)

38 Heere C, Skeaff CM, Waqatakirewa L, Vatucawaqa P, Khan AN \& Green TJ. Serum 25-hydroxyvitamin D concentration of IndigenousFijian and Fijian-Indian women. Asia Pacific Journal of Clinical Nutrition 201019 43-48.

39 G R \& Gupta A. Vitamin D deficiency in India: prevalence, causalities and interventions. Nutrients 20146 729-775. (https://doi. org/10.3390/nu6020729)

40 Kimlin MG, Lucas RM, Harrison SL, van der Mei I, Armstrong BK, Whiteman DC, Kricker A, Nowak M, Brodie AM \& Sun J. The contributions of solar ultraviolet radiation exposure and other https://ec.bioscientifica.com https://doi.org/10.1530/EC-20-0206 (c) 2020 The authors Published by Bioscientifica Ltd

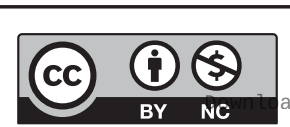

This work is licensed under a Creative Commons Attribution-NonCommercial 4.0 International License. ded from Bioscientifica.com at 04/26/2023 10:07:44AM 
determinants to Serum 25-hydroxyvitamin D concentrations in Australian adults: the AusD study. American Journal of Epidemiology 2014179 864-874. (https://doi.org/10.1093/aje/kwt446)

41 Ling Y, Lin H, Aleteng Q, Ma H, Pan B, Gao J \& Gao X. Cdx-2 polymorphism in vitamin $\mathrm{D}$ Receptor gene was associated with serum 25-hydroxyvitamin D levels, bone mineral density and fracture in middle-aged and elderly Chinese women. Molecular and Cellular Endocrinology 2016427 155-161. (https://doi.org/10.1016/j. mce.2016.03.014)

42 Mezzavilla M, Tomei S, Alkayal F, Melhem M, Ali MM, Al-Arouj M, Bennakhi A, Alsmadi O \& Elkum N. Investigation of genetic variation and lifestyle determinants in vitamin D levels in Arab individuals. Journal of Translational Medicine 201816 20. (https://doi.org/10.1186/ s12967-018-1396-8)

43 Uitterlinden AG, Fang Y, van Meurs JBJ, Pols HAP \& van Leeuwen JPTM. Genetics and biology of vitamin D receptor polymorphisms. Gene 2004 338 143-156. (https://doi.org/10.1016/j.gene.2004.05.014)

44 Jiang X, Kiel DP \& Kraft P. The genetics of vitamin D. Bone 2019126 59-77. (https://doi.org/10.1016/j.bone.2018.10.006)

45 Nissen J, Rasmussen LB, Ravn-Haren G, Andersen EW, Hansen B, Andersen R, Mejborn H, Madsen KH \& Vogel U. Common variants in CYP2R1 and GC genes predict vitamin D concentrations in healthy Danish children and adults. PLOS ONE 20149 e89907. (https://doi. org/10.1371/journal.pone.0089907)

46 Husain NE, Badie Suliman AA, Abdelrahman I, Bedri SA, Musa RM, Osman HE, Mustafa AH, Gafer N, Farah E, Satir AA, et al. Vitamin $\mathrm{D}$ level and its determinants among Sudanese women: does it matter in a sunshine African country? Journal of Family Medicine and Primary Care 20198 2389-2394. (https://doi.org/10.4103/jfmpc. jfmpc_247_19)

47 Dirks NF, Ackermans MT, Lips P, de Jongh RT, Vervloet MG, de Jonge R \& Heijboer AC. The when, what and how of measuring vitamin D metabolism in clinical medicine. Nutrients 201810482. (https://doi.org/10.3390/nu10040482.

48 Ferreira CE. Consensus - reference ranges of vitamin D [25(OH)D] from the Brazilian medical societies. Brazilian Society of Clinical Pathology/Laboratory Medicine (SBPC/ML) and Brazilian Society of Endocrinology and Metabolism (SBEM). Jornal Brasileiro de Patologia e Medicina Laboratorial 201753 377-381.
49 Filgueiras MS, Suhett LG, Silva MA, Rocha NP \& de Novaes JF. Lower vitamin D intake is associated with low HDL cholesterol and vitamin D insufficiency/deficiency in Brazilian children. Public Health Nutrition 201821 2004-2012. (https://doi.org/10.1017/ S1368980018000204)

50 Peters BSE, dos Santos LC, Fisberg M, Wood RJ \& Martini LA. Prevalence of vitamin D insufficiency in Brazilian adolescents. Annals of Nutrition and Metabolism 200954 15-21. (https://doi. org/10.1159/000199454)

51 Cembranel F, Hallal ALC, González-Chica DA \& d'Orsi E. Relação entre consumo alimentar de vitaminas e minerais, índice de massa corporal e circunferência da cintura: um estudo de base populacional com adultos no Sul do Brasil. Cadernos de Saúde Pública 201733 e00136616. (https://doi.org/10.1590/0102-311X00136616)

52 Fisberg RM, Marchioni DML, de Castro MA, Verly Junior E, Araújo MC, Bezerra IN, Pereira RA \& Sichieri R. Ingestão inadequada de nutrientes na população de idosos do Brasil: inquérito Nacional de Alimentação 2008-2009. Revista de Saúde Pública 201347 (Supplement 1) 222s-230s. (https://doi.org/10.1590/S0034$89102013000200008)$

53 Libon F, Cavalier E \& Nikkels AF. Skin color is relevant to vitamin D synthesis. Dermatology 2013227 250-254. (https://doi. org/10.1159/000354750)

54 Xiang F, Lucas R, de Gruijl F \& Norval M. A systematic review of the influence of skin pigmentation on changes in the concentrations of vitamin D and 25-hydroxyvitamin D in plasma/serum following experimental UV irradiation. Photochemical and Photobiological Sciences 201514 2138-2146. (https://doi.org/10.1039/ C5PP00168D)

55 Brazilian Institute of Geography and Statistics. Table 2094 - Resident population by color or race and religion. Rio de Janeiro, Brazil: IBGE. (available at: https://sidra.ibge.gov.br/tabela/2094\#/n1/all/n2/all/ n3/all/v/1000093/p/last\%201/c86/allxt/c133/0/d/v1000093\%20 $1 / 1 / \mathrm{v}, \mathrm{p}+\mathrm{c} 86, \mathrm{t}+\mathrm{c} 133 /$ resultado)

56 Munns CF, Shaw N, Kiely M, Specker BL, Thacher TD, Ozono K, Michigami T, Tiosano D, Mughal MZ, Mäkitie O, et al. Global consensus recommendations on prevention and management of nutritional rickets. Journal of Clinical Endocrinology and Metabolism 2016101 394-415. (https://doi.org/10.1210/jc.2015-2175)

Received in final form 2 June 2020

Accepted 18 June 2020

Accepted Manuscript published online 19 June 2020
This work is licensed under a Creative Commons Attribution-NonCommercial 4.0 International License. ded from Bioscientifica.com at 04/26/2023 10:07:44AM 